ISSN (Print) : 1412-7601

ISSN (Online): 2654-8712

Volume 7, No.2 September 2021

EKONOBIS

http://www.ekonobis.unram.ac.id

\title{
Survey Pekerja Sektor informal Dan Sektor Formal Era Revolusi Industri di Kota Mataram
}

\author{
Satarudin, Suprianto, Sujadi. \\ Universitas Mataram
}

ARTICLE INFO

Keywords:

Survey, formal worker, informal workers, Mataram City

ABSTRACT: The research objective was to analyze the income and welfare level of informal and formal sector workers in the city of Mataram. The research method was carried out by means of a survey by taking a sample of 90 respondents, and the determination of the respondents was determined purposively by looking at the characteristics of the two workers. The characteristics of informal and formal workers mostly sell in crowded places and visitors in the city of Mataram can be seen from the level of education that $56.7 \%$ have education equivalent to high school and above and $43.3 \%$ have graduated from SMP and SD with an average level of education. The average length of time working is more than 10 hours a day, while the average family dependents of informal and formal workers are between 2 and 4 dependents. The average income earned by informal workers is Rp. $3,000,000$, - as much as $16.67 \%$ and $44.45 \%$ of the income is above $R p$. $3,000,000$, - while the average income of formal workers is above Rp. 4,000,000, as many as $8,89 \%$ of the remaining income above IDR 6,000,000 as much as $30 \%$. Overall, if the analysis of the income of informal and formal workers is related to the welfare level of the Sayogyo criteria with a rice equivalent, the category of near-poor is 10\% (9 workers, namely clockworkers, shoe soles and vegetable traders), with an expenditure / capita / year of 450. $\mathrm{kg}$ equivalent value of rice / year. Meanwhile, 40\% (36 respondents) were at the sufficient threshold with a per capita / year expenditure of $481-960 \mathrm{~kg}$ as a result of analysis an average of $750 \mathrm{~kg}$ equivalent to rice. A decent living category if the expenditure per capita / year is higher than $960 \mathrm{~kg}$ equivalent to the value of rice / year. The average per capita income of formal and informal workers is IDR 11.2550.000, - if divided by the price of rice during the study of IDR 10,000 per $\mathrm{kg}$, the result is that $1.125 \mathrm{~kg}$ of rice means that almost $50 \%$ of the workers are in a decent life, consisting of 35 respondents. formal workers and 10 respondents to informal workers. To further increase the income of informal workers, in particular, increase the work act of at least 15 hours per day and open a digital system sales service via the internet (go food, go jek) especially for traders of cooked food such as restaurants, vegetables, rice traders and so on.

Kata Kunci:

Survey, Pekerja formal, Pekerja informal, Kota Mataram
ABSTRAK: Tujuan penelitian adalah untuk menganalisis Pendapatan dan Tingkat kesejahteraan Pekerja sektor Informal dan Formal di Kota Mataram pada era Covid 19. Metode penelitian dilakukan dengan cara survey dengan mengambil sampel sebanyak 90 orang responden, dan penentuan responden ditentukan secara accidental dengan melihat karakteristik dari kedua pekerja tersebut.Karakteristik dari pekerja informal dan formal sebagian besar berjualan ditempat-tempat keramaian yang padat penduduk dan pengunjung di wilayah kota Mataram dilihat dari tingkat pendidikan $56,7 \%$ memiliki pendidikan setara SMA ke atas dan 43,3\% tingkat pendidikan tamat $S M P$ dan SD dengan rata-rata lama waktu bekerja di atas 10 jam sehari, sedangkan rata-rata tanggungan keluarga pekerja informal dan formal antara 2 sampai 4 orang tanggungan. Rata-rata pendapatan yang diperoleh pekerja informal dibawah $R p$ 3.000.000,- sebanyak 16,67\% dan 44,45\% pendapatannya di atas $R p$ 3.000,000,Sedangkan pendapatan pekerja formal rata-rata di atas $R p$ 4.000.000, sebanyak 8,89 \% selebihnya pendapatan di atas Rp 6.000 .000 sebanyak $30 \%$. Secara keseluruhan analisis pendapatan pekerja informal dan formal jika dikaitkan dengan tingkat kesejahteraan kriteria Sayogjo dengan ukuran setara beras, maka kategori nyaris miskin sebanyak $10 \%(9$ orang pekerja yaitu jasa tukang jam, jahit sepatu dan pedagang sayuran), dengan pengeluaran /kapita/tahun sebanyak $450 \mathrm{~kg}$ setara nilai 


\begin{tabular}{l|l}
\hline beras/tahun. Sedangkan $40 \%$ (36 responden) berada pada batas ambang cukup \\
dengan pengeluaran perkapita/tahun $481-960 \mathrm{~kg}$ hasil analisis rata-rata sebesar 750 \\
kg setara beras. Kategori hidup layak apabila pengeluaran perkapita/tahun lebih \\
tinggi dari $960 \mathrm{~kg}$ setara nilai beras /tahun. Rata-rata pendapatan perkapita pekerja \\
formal dan informal sebesar $\mathrm{Rp} 11.2550 .000,-$ jika dibagi dengan harga beras saat \\
penelitian $\mathrm{Rp} 10.000,-$ perkg, maka hasilnya $1.125 \mathrm{~kg}$ beras berarti hampir $50 \%$ \\
pekerja berada pada kehidupan yang layak yaitu terdiri dari 35 responde pekerja \\
formal dan 10 responden pekerja informal. Untuk lebih meningkatkan pendapatan \\
pekerja informal khususnya lebih meningkatkan waktu bekerja minimal 15 jam per \\
hari dan membuka layanan penjualan sistem digital via internet (go food, go jek) \\
khususnya bagi pedagang makanan matang seperti rumah makan, lalapan, pedagang \\
nasi dan sebagainya.
\end{tabular}

Corresponding Author:

Alamat: Program Studi Ekonomi Pembangunan, Fakultas Ekonomi dan Bisnis, Universitas Mataram, Jln. Majapahit No. 62 Mataram.

e-mail: satarudin@unram.ac.id

2021, EKONOBIS All right reserved 


\section{PENDAHULUAN}

Latar Belakang

Angkatan kerja Indonesia sangat besar, lapangan kerja terbatas, tingkat partisipasi kerja menurun dan struktur pasar tenaga kerja di Indonesia pun berubah relatif cepat. Hal ini mengakibatkan tingkat pengangguran di Indonesia menjadi semakin tinggi. Indonesia sebagai Negara yang besar tentunya memiliki angkatan kerja yang sangat besar. Lalu,struktur pasar tenaga kerja di Indonesia pun berubah relatif cepat hal ini disebabkan adanya pergeseran struktur perekonomian yang deuasa ini dominasi oleh sektor industri, perdagangan dan industri pariuisata.

Bukan hanya tingkat pengangguran yang relatif masih tinggi jika dibandingkan dengan negara-negara lain di kawasan Asia, masalah lain yang harus dicermati pemerintah adalah pasar tenaga kerja Indonesia masih didominasi oleh sektor informal. Data BPS mencatat, dari 100\% lapangan kerja di Indonesia per Februari 2019, sebanyak $57,27 \%$ disumbang oleh sektor informal.Dalam beberapa waktu terakhir, kontribusi sektor informal terhadap total pasar tenaga kerja Indonesia terus mendekati level $60 \%$.Untuk diketahui, yang membedakan lapangan kerja formal dan informal adalah terkait dengan pembayaran pajak ke pemerintah. Tenaga kerja formal merupakan tenaga kerja yang membayarkan pajak kepada pemerintah. Biasanya, tenaga kerja formal merupakan seorang profesional seperti guru, dosen, dokter, wartawan, dan Aparatur Sipil Negara (ASN).Sementara itu, tenaga kerja informal merupakan tenaga kerja yang tidak membayarkan pajak kepada pemerintah, walaupun sejatinya penghasilannya masuk ke dalam kategori yang dikenakan pajak penghasilan (PPh). Tenaga kerja informal biasanya diasosiasikan dengan tenaga kerja yang banyak mengandalkan kekuatan fisik (blue collar) seperti Pedagang Kaki Lima (PKL), kuli bangunan, dan tukang ojek.

Pengertian sektor informal sering dikaitkan dengan ciri-ciri utama pengusaha dan pelaku sektor informal, antara lain kegiatan usaha bermodal utama pada kemandirian rakyat, memanfaatkan teknologi sederhana, pekerjanya terutama berasal dari tenaga keluarga tanpa upah, bahan baku usaha kebanyakan memanfaatkan sumberdaya lokal, sebagian besar melayani kebutuhan rakyat kelas menengah kebaah, pendidikan dan kualitas sumberdaya pelaku tergolong rendah. (Direktorat Ketenaga Kerjaan ; 2019).

Kondisi ini tidak jauh berbeda dialami oleh Provinsi Nusa Tenggara Barat dalam menghadapi persaingan kerja di era digitalisasi khususnya sektor informal dan sektor formal di Kota Mataram sebagai ibu kota provinsi yang merupakan baro meter denyut kehidupan masyarakat NTB dari segala aspek baik sebagai kota perdagangan, pendidikan maupun sebagai ikon kota pariwisata yang sudah barang tentu kota Mataram menjadi tumpuan bagi para pencari kerja baik di sektor formal maupun informal.

Berdasarkan data BPS NTB, jumlah angkatan kerja pada Februari 2019 sebanyak 2.489 .388 orang, naik 30.367 orang dibanding Februari 2018. Tingkat Partisipasi Angkatan Kerja (TPAK) pada Februari 2018 sebesar 69,83 persen sedangkan pada Februari 2019 menjadi 69,62 persen. Penduduk yang bekerja sebanyak 2.408.095 orang, bertambah 32.284 orang dari Februari 2018.Sebanyak 1.635.422 orang (67,91 persen) bekerja pada kegiatan informal dan sebanyak 772.673 orang bekerja di kegiatan formal. Selama setahun terakhir (Februari 2018Februari 2019), pekerja informal turun sebesar 3,60 persen(Suara NTB; 29 Sep 2019). Persentase tertinggi pada Februari 2019 adalah pekerja penuh (jam kerja 
minimal 35 jam per minggu) sebesar 60,36 persen. Sedangkan penduduk yang bekerja dengan jam kerja 1-7 jam memiliki persentase yang paling kecil, yaitu sebesar 5,78 persen. Sementara itu, pekerja tidak penuh terbagi menjadi dua, yaitu pekerja paruh waktu (25,40 persen) dan pekerja setengah penganggur (14,24 persen).

Hasil kajian Badan Pusat Statistik (BPS) Nasional (Februari ;2019), bahua perkembangan sektor informal ini dipicu dari dua sisi yaitu pertama; perkembangan ekonomi digital dan teknologi sehingga memacu tumbuhnya uirasasta baru secara on-line. Selain itu pertumbuhan sektor informal juga dipengeruhi dari karakteristik kaum milenial yang cenderung memilih jam kerja fleksibel. Mengacu pada ilustrasi gambaran potret ketenaga kerjaan NTB baik di sektor informal maupun sektor formal muaranya secara umum tertuju pada kota Mataram karena kota Mataram memiliki daya tarik bagi pencari kerja apakah pekerja disektor informal yang sekarang ini semakin bertambah dengan tumbuhnya pedagangpedagang kuliner maupun pedagang kaki lima dan usaha makanan on line, disisi lain kompetisi pencari kerja di sektor formal juga semakin meningkat baik untuk masuk pada pasar tenaga kerja pemerintah maupun suasta dengan berbagai skill atau keahlian yang dimiliki dengan berbagai tingkat kelulusan baik dari lulusan Sekolah Menengah Keatas (SMA) sederajat, diploma dan perguruan tinggi. Sesuatu yang menarik untuk dikaji dan dikemas dalam suatu survey Pekerja sektor Informal maupun formal di era digital di Kota Mataram.

\section{Rumusan Masalah}

Dari latar belakang di atas dapat dirumuskan permasalahan sebagai berikut:

1. Bagaimana frofil pekerja sektor informal dan pekerja formal pada era industri digital di Kota Mataram.
2. Bagaimana tingkat pendapatan dan kesejahteraan pekerja sektor informal dan formal pada era digital di kota Mataram.

\section{Tujuan Penelitian}

1. Untuk mengetahui profil pekerja sektor informal maupun formal pada era industri digital di Kota Mataram.

2. Untuk menganalisis tingkat pendapatan dan tingkat kesejahteraan pekerja sektor informal dan formal melaui bisnis online di Kota Mataram lokal

\section{KAJIAN PUSTAKA}

\section{Pengertian Sumberdaya Manusia}

Kualitas SDM Indonesia yang didominasi oleh lulusan SD dan SMP menjadikan Indonesia belum dapat berpartisipasi dalam lapangan kerja baru yang terbentuk di Industri 4.0 yang membutuhkan skill dan kompetensi yang tinggi, yang ada SDM indonesia hanya akan menjadi pekerja dalam rantai terujung atau terakhir dari proses produksi dimana hanya melakukan pekerjaan yang memiliki upah yang rendah. Berdasarkan survei yang dilakukan oleh Asosiasi Penyelenggara Jasa Internet Indonesia (APJII) menunjukkan bahwa pada tahun 2018 penetrasi pengguna Internet di Indonesia mencapai angka 143,26 juta jiwa atau setara 54,7 persen dari total populasi Indonesia. Hal ini sebenarnya dapat menjadi sebuah acuan dimana kesiapan Indonesia dalam menghadapi Industri 4,0 sangat tinggi karena sebagian besar penduduk sudah familiar dengan internet.

Namun jika dilihat lebih jauh lagi ternyata 130 juta jiwa diantaranya atau setara 49\% masih menggunakan internet untuk bermain sosial media saja, belum pada tingkat yang lebih dalam. Sehingga dapat disimpulkan walaupun tingkat penetrasi pengguna internet di Indonesia tinggi, namun masyarakat belum siap dalam menggunakan sistem internet yang lebih rumit dan sulit dalam era industri digital. 
Menanggapi berbagai permasalahan SDM yang muncul dalam menghadapi Industri 4.0, pemerintah menerapkan beberapa kebijakan untuk meningkatkan kualitas SDM. Salah satunya adalah dengan menciptakan kurikulum berbasis kompetensi yang tersambung dan sesuai (Link and Match) dengan industri, sehingga nantinya lulusan yang dihasilkan dapat memiliki kompetensi yang sesuai dengan kebutuhan industri dan professional. Dengan ini maka nantinya diharapkan SDM Indonesia dapat menempati berbagai lapangan kerja baru yang muncul pada Industri 4.0

\section{Pasar Tenaga Kerja}

Kondisi Covid 19 membaua dampak keberbagai sektor perekonomian Indonesia, hal ini mengakibatkan banyak terjadi pemutusan hubungan kerja atau tenaga kerja yang dirumahkan. Mentri Ketenaga kerjaan Ida Fauziah(dikutip dari Kontan 8/07/2020) mengatakan, sejak 1 April hingga 27 Mei 2020 terdapat 1,75 juta tenaga kerja formal dan informal yang terdampak covid-19. Pekerja formal yang dirumahkan dan mengalami pemutusan hubungan kerja (PHK) mencapai 1,43 juta orang pekerja dan yang terdampak PHK sebanyak 380.221 pekerja dan yang dirumahkan mencapai 1.058.284 pekerja. Sementara pekerja sektor informal yang terdampak sebanyak 318.959 orang dn ini bisa lebih besr lagi karena data yang masuk kebanyakan data pekerja formal.

Sementara pekerja sektor informal merupakan pekerja yang berusaha sendiri dan pekerja bebas disektor pertanian dan non pertanian seperti pedgang kaki lima, sopir angkot, tukang sepatu, tukang becaak. Jika dilihat dari catatan BPS pada tahun 2019 rata-rata upah pekerja sektor informal di Indonesia sebesar Rp 1.816.000 per bulan. Namun demikian besaran jumlah upah yang diterima oleh pekerja informal pun berbeda di tiap daerah, upah tertinggi pekerja informal di DKI Jakarta Rp 3.515.000,-

Jika dianalisis untuk setiap lapangan pekerjaan, kesenjangan upah di tiap daerah antara gender juga dihadapi pada semua lapangan pekerjaan di Indonesia. Pada tahun 2015, kesenjangan terbesar ada pada lapangan pekerjaan pertanian, kehutanan, dan perikanan. Pada lapangan pekerjaan tersebut, pekerja perempuan hanya mendapatkan upah 56,49 persen dari upah yang diterima oleh pekerja lakilaki. Besarnya kesenjangan upah antar gender pada pertanian disebabkan karena jenis pekerjaan pada lapangan pekerjaan tersebut lebih mengandalkan tenaga dan fisik.

Secara umum, kesenjangan upah antar gender dipengaruhi oleh jenis dan posisi pekerjaan yang ditempati oleh pekerja perempuan dan pekerja laki-laki. Beberapa jenis dan posisi pekerjaan dengan upah yang tinggi hanya didominasi oleh pekerja laki-laki. Tidak hanya secara umum, kesenjangan upah juga dapat dilihat dari masing-masing jenis pekerjaan. Pada tahun 2015, perempuan mengalami kesenjangan upah di semua jenis pekerjaan. Kesenjangan terbesar ada pada tenaga usaha jasa. Tenaga usaha jasa yang dimaksud seperti pelayanan pribadi dan perlindungan yang berkaitan dengan perjalanan, kerumahtanggaan, katering, perawatan pribadi, atau perlindungan terhadap kebakaran dan tindakan pelanggaran hukum. Pada jenis pekerjaan tersebut, pekerja perempuan hanya menerima upah setengahnya dari upah pekerja laki-laki.

\section{Sektor Informal Dan Sektor Formal}

Sektor Usaha Formal adalah lapangan atau bidang usaha yang mendapat izin dari pejabat berwenang dan terdaftar di kantor pemerintahan. Badan usaha tersebut apabila dilihat di kantor pajak maupun kantor perdagangan dan perindustrian terdaftar nama dan bidang usahanya (Hestanto; 2016). 
Ciri-ciri:

1. Adanya izin mendirikan usaha dari pemerintah (SIUP)

2. Ada Akta Pendirian oleh Notaris

3. Memiliki pembukuan/Laporan Kuangan yang Jelas

4. Rutin Melaporkan Keuangan ke Kantor Pajak

Sektor Usaha Informal yaitu bidang usaha yang tidak memiliki keresmian usaha dan usaha tsb tidak memiliki izin dari pemerintah dan tidak terdaftar di lembaga pemerintahan.

Ciri-ciri:

1. Tidak memiliki izin usaha

2. Modal relatif kecil

3. Peralatan yang digumakan sederhana

4. Tidak terkena pungutan pajak

5. Administrasi tidak punya/sangat sederhana Contoh: warung makan, Pedagang Asongan, Pedagang Keliling, Tulang jahit sepatu

Sektor informal memiliki peran yang besar di negara-negara sedang berkembang (NSB) termasuk Indonesia. Sektor informal adalah sektor yang tidak terorganisasi (unorganized), tidak teratur (unregulated), dan kebanyakan legal tetapi tidak terdaftar (unregistered).

Menurut Hestanto(2016), sektor informal memiliki karakteristik seperti jumlah unit usaha yang banyak dalam skala kecil; kepemilikan oleh individu atau keluarga, teknologi yang sederhana dan padat tenaga kerja, tingkat pendidikan dan ketrampilan yang rendah, akses ke lembaga keuangan daerah, produktivitas tenaga kerja yang rendah dan tingkat upah yang juga relatif lebih rendah dibandingkan sektor formal.Penggunaan modal pada sektor informal relatif sedikit bila dibandingkan dengan sektor formal sehingga cukup dengan modal sedikit dapat memeprkerjakan orang. Dengan menyediakan akses pelatihan dan ketrampilan, sektor informal dapat memiliki peran yang yang besar dalam pengembangan sumber daya manusia. Sektor informal memunculkan permintaan untuk tenaga kerja semiterampil dan tidak terampil. Sektor informal biasanya menggunakan teknologi tepat guna dan menggunakan sumber daya local sehingga akan menciptakan efisiensi alokasi sumber ormal bahwa kebanyakan pekerja di sektor informal perkotaan merupakan migran dari desa atau daerah lain. Motivasi pekerja adalah memperoleh pendapatan yang cukup untuk sekedar mempertahankan hidup (survival).

\section{Pendapatan Dan Kesejahteraan}

Pendapatan adalah salah satu indicator untuk melihat kesejahteraan masyarakat. Setiap orang berkeinginan untuk mencapai kehidupan sejahteran atau hidup sejahtera, dengan berbagai kriteria yang digunakan untuk mengukur kesejahteraan. Secara mikro kesejahteraan rumah tangga dapat didekati dengan hukum Engel, yang menyatakan pangsa pengeluaran makanan terhadap pengeluaran rumah tangga akan semakin berkurang dengan pendapatan yang meningkat. Lebih lanjut dalam keadaan harga barang dan selera masyarakat tetap maka peningkatan pendapatan menunjukkan peningkatan kesejahteraan (Nicholson, 2002).

Setiap orang memiliki keinginan untuk membuat dirinya hidup sejahtera, yaitu suatu keadaan yang membaut dirinya serba baik atau suatu kondisi dimana orang-orang dalam keadaan hidup makmur atau berkecukupan, sehat dan rasa damai. Undang- Undang Nomor 11 Tahun 2009, tentang kesejahteraan sosial menyebutkan bahwa keadaan sejahtera yaitu suatu tatakehidupan dan penghidupan sosial, baik material maupun spiritual diliputi oleh rasa keselamatan, kesusilaan dan ketentraman. 
Menurut Spickerdkk (dalam Suharto,2006), pengertian kesejahteraan sedikitnya mengandung empat makna, yaitu sebagai berikut:

Pertama, sebagai kondisi sejahtera (wellbeing). Pengertian ini biasanya menunjuk pada istilah kesejahteraan sosial (sosial welfare) sebagai kondisi terpenuhinya kebutuhan material dan non material. Kondisi sejahtera terjadi manakala kehidupan manusia aman dan bahagia karena kebutuhan dasar akan gizi, kesehatan, pendidikan, tempat tinggal dan pendapatan dapat dipenuhi.

Kedua, sebagai pelayanan sosial dalam bentuk jaminan sosial (sosial security), pelayanan kesehatan, pendidikan, perumahan dan pelayanan sosial personal (personal sosial services).

Ketiga, sebagai tunjangan sosial, yang khususnya diberikan kepada orang miskin, karena sebagian besar penerima walfare adalah orang-orang miskin, cacat, pengangguran.

Ketiga, sebagai tunjangan sosial, yang khususnya diberikan kepada orang miskin, karena sebagian besar penerima walfare adalah orang-orang miskin, cacat, pengangguran.

Keempat, sebagai proses atauusahaterencana yang dilakukan baik oleh perorangan, lembaga sosial, masyarakat maupun badan-badan pemerintah untuk meningkatkan kualitas kehidupan melalui pemberian pelayanan sosial dan tunjangan sosial.

Menurut Sajogyo dalam

Murdani, dkk (2015), menjelaskan pengukuran kesejahteraan didasari atas kriteria garis kemiskinan. Kriteria tersebut meliputi; rumahtangga paling miskin, rumah tangga miskin sekali, rumah tangga miskin, rumah tangga nyaris miskin, rumah tangga cukup dan rumah tangga hidup layak. Salah satu indikator untuk mengukur tingkat kesejahteraan adalah pendapatan yang diperoleh masyarakat. Oleh karena itu penelitian ini bertujuan untuk melihat pendapatan pekerja informal dan formal di era industri digital di kota Mataram.

\section{Kajian Penelitian Terdahulu}

Berdasarkan hasil penelitian Yustina Chrismardani, Bondan S(2018) bahwa pekerja sektor formal yang termasuk dalam kategori pekerjan/ pekerja dan berusaha dibantu oleh pekerja tetap / pekerja dibayarhingga 76 persen, dan pekerja informal adalah yang mencoba sendiri, berusaha menjadidibantu oleh pekerja sementara, pekerja gratis di pertanian, pekerja bebassecara non-bayar mencapai 24 persen. Temuan penting lainnya menunjukkan hal itutidak ada perbedaan signifikan dalam total pendapatan pekerja disektor informal dan formal, yang rata-rata $\mathrm{Rp} 76.184$, dan ternyatabahwa Kabupaten Bangkalan belum menjadi target migrasi pekerjadari daerah sekitarnya.

Penelitian yang dilakukan oleh Yupi Kurniauan,S dan Rr. Retno Arnanti(2014), bertujuan untuk menggambarkan pengelolaan sumber daya manusia dan perbedaan pengelolaan sumber daya manusia pada sektor formal dan sektor informal di Jawa Timur. Jenis penelitian ini kuantitatif deskriptif, dengan teknik pengumpulan data yang dilakukan melalui penyebaran kuesioner pada wirausaha sektor formal dan informal di Jawa Timur. Sebelum dilakukan analisa statistik deskriptif dan uji T terlebih dahulu dilakukan uji validitas dan reliabilitas yang telah teruji. Berdasarkan hasil analisa data yang didapat, ditemukan pengelolaan sumber daya manusia di Jawa Timur tergolong dalam kategori sedang. Ditemukan pula aspek yang paling terbaik dalam pengelolaan sumber daya manusia di Jawa Timur yaitu penilaian prestasi kerja. Berdasarkan uji $T$ variabel independen pengelolaan sumber daya manusia sektor formal dan informal di Jawa Timur tidak terdapat perbedaan yang signifikan secara keseluruhan. 
Hasil kajian Badan Pusat Statistik (BPS) Nasional(Februari,2019), bahua jumlah penduduk berumur 15 tahun keatas yang bekerja disektor informal tahun 2015 sejumlah 67 juta orang pekerja dan pada tahun 2019 jumlah pekerja sektor informal telah mencapai 74 juta orang pekerja. BPS juga mencatat sektor informal mendominasi pekerjaan di Indonesia sementara itu penduduk yang bekerja di sektor formal hanya mencapai 55,3 juta orang pekerja.

\section{Jenis Penelitian dan Sumber Data}

Penelitian ini menggunakan metode analisis deskriptif yaitu untuk meneliti status kelompok manusia, suatu obyek, suatu set kondisi, suatu sistem pemikiran ataupun suatu kelas peristiua pada masa sekarang (Nazir; 2011). Metode deskriptif menggambarkan peristia secara sistematis, faktual dan akurat mengenai fakta, sifat dan hubungan antar fenomena yang diteliti. Penelitian ini bertujuan untuk membuat gambaran atau lukisan secara sistimatis, faktual dan akurat mengenai kinerja pemasaran produk agroindustri olahan di daerah penelitian.

Penelitian ini menggunakan data primer dan data sekunder sebagai pendukung analisis. Data primer diperoleh langsung dari responden yaitu pekerja disektor informal dan pekerja disektor formal dengan melakukan uauancara lansung kepada responden yang dituju. Sedangkan data sekunder adalah data yang diperoleh dari instansi terkait seperti BPS Kota Mataram, Kantor Ketenagakerjaan Kota Mataram dan berbagai literatur yang ada kaitannya dengan penelitian ini.

\section{Metode Pengumpulan Data}

dengan melakukan pendataan langsung kepada obyek yang diteliti dengan mengambil sampel sebanyak 90 responden sesuai dengan kebutuhan penelitian yang terdiri dari pekerja disektor informal sebanyak 55 responden dan pekerja di sektor formal sebanyak 35 responden. Tujuan penelitian survey adalah untuk meneliti tentang karakteristik dari seluruh kelompok yang hendak diteliti atau populasi dengan meneliti sebagian (sub-set) dari kelompok populasi tersebut yang selanjutnya disebut dengan sampel. Hasil dari survey terhadap sampel tersebut kemudian digeneralisasikan atau diberlakukan kepada populasi. Penelitian survey biasanya didefinisikan sebagai sebuah penelitian atau penelitian tentang kelompok besar melalui penelitian langsung dari subset (sampel) dari kelompok tersebut.

Penentuan responden dibagi dalam pekerja usaha di sektor informal yaitu(pedagang asongan, pedagang kaki lima, pedagang keliling, bengkel kecil, tukang jahit sepatu). Sedangkan untuk pekerja yang bekerja pada sektor formal, yaitu sektor selain sektor informal, meliputi berusaha sendiri yang berijin dan membayar pajak, berusaha dibantu pekerja tidak tetap, pekerja bebas. Karena gambaran populasi responden tidak diketahui jumlahnya maka dalam penentuan sampel digunakan teknik non random sampling yaitu menggunakan teknik Accidental Sampling. Menurut Sugiyono $(2018 ; 138)$ teknik penentuan sampel berdasarkan kebetulan, yaitu pekerja informal/formal yang secara kebetulan/incidental bertemu dengan peneliti dapat digunakan sebagai sampel, bila orang yang kebetulan ditemui itu cocok sebagai sumber data.

\section{Metode Analisis Data}

Analisis dilakukan dengan menggunakan analisis data kualitatif dan kuantitatif dengan menggunakan data primer yang dikumpulkan melalui hasil wawancara dengan bantuan daftar pertanyaan. Kemudian analisis dilakukan dengan analisis tabel baik tabel frekensi maupun menggunakan tabel silang.

Selanjutnya untuk mengetahui tingkat pendapatan dan kesejahteraan pekerja 
sektor informal dan formal digunakan analisi sebagai berikut:

1.Analisis usaha dan biaya, yaitu mengetahui pendapatan pekerja sektor informal yaitu dengan formula sebagai berikut:

$$
\begin{aligned}
& \Pi=\mathrm{TR}-\mathrm{TC} \\
& \mathrm{TR}=\mathrm{Y} . \mathrm{PY} \\
& \mathrm{TC}=\mathrm{TFC}+\mathrm{TVC}
\end{aligned}
$$

Dimana:

$$
\begin{aligned}
\mathrm{TR}= & \text { Total penerimaan (Total Revenue } \\
& \text { dalam rupiah) } \\
\mathrm{TC}= & \text { Total Biaya (dalam Rupiah) }
\end{aligned}
$$

$$
\begin{aligned}
\mathrm{Y}= & \text { Produksi yang diperoleh } \\
\mathrm{Py}= & \text { Harga } \mathrm{Y} \\
\mathrm{TVC}= & \text { Total Biaya Variabel (dalam } \\
& \text { Rupiah) } \\
\mathrm{TFC}= & \text { Total biaya Tetap (dalam Rupiah) }
\end{aligned}
$$

\begin{tabular}{|c|c|c|}
\hline \multicolumn{2}{|r|}{ No Uraian } & Tingkat Kesejahteraan /Kapita/Tahun \\
\hline 1 & RT Paling Miskin & $<180 \mathrm{Kg}$ Setara beras \\
\hline 2 & RT MiskinSekali & $181-240 \mathrm{Kg}$ setara beras \\
\hline 3 & RT Miskin & $241-320 \mathrm{Kg}$ setara beras \\
\hline 4 & RT NyarisMiskin & $321-480 \mathrm{Kg}$ setara beras \\
\hline & RT HidupCukup & 481 - $960 \mathrm{Kg}$ setara beras \\
\hline 6 & RT HidupLayak & $>960 \mathrm{Kg}$ setara beras \\
\hline
\end{tabular}

2.Pengukuran derajat kesejahteraan pekerja informal dan formal menggunakan batas garis kemiskinan,sebagaimana dikemukakan oleh Sajogyo dalam Murdani, dkk (2015) terdiri dari beberapa criteria sebagai berikut:

Tabel 1. Kriteria Garis Kemiskinan Sajogyo

Sumber: Sajogyo dalam Murdani dkk(2015)

\section{HASIL DAN PEMBAHASAN}

\section{Gambaran Wilayah Kota Mataram}

Kota Mataram merupakan kota Ibu kota dari Provinsi Nusa Tenggara Barat yang berdiri tahun 1986 dengan wilayah meliputi Kecamatan Mataram, Kecamatan Cakranegara dan Kecamatan Ampenan. Dengan perkembangan kota yang sangat pesat dibarengi dengan pertumbuhan penduduk maka kota Mataram menjadi tumpuan kehidupan berbagai komunitas usaha dan baik bagi pekerja sector informal maupun pekerja sector formal. Sebagai ibu kota provinsi juga merupakan pusat pemerintahan, perdagangan dan pendidikan tumbuh berbagai aktivitas masyarakat kota Mataram dengan berbagai bentuk usaha baik usaha mikro maupun usaha kecil menengah yang bergerak dibidang usaha industry, perdagangan maupun jasa.

Kota Mataram dibagi menjadi tiga wilayah yaitu wilayah Kota Cakranegara, Wilayah Kota Mataram dan wilayah kota tua Ampenan dan secara demografis penduduk di kota Mataram tersebar di 5 (lima) kecamatan yaitu; kecamatan Cakranegara, kecamatan Sandubaya, kecamatan Selaparang, kecamatan Ampenan, kecamatan Mataram dan kecamatan Sekarbela dengan penyebaran penduduk sebagai berikut:

Tabel 2. Jumlah Penduduk Kota Mataram Berdasarkan Jenis Kelamin Tahun 2018-2020

\begin{tabular}{|c|ccc|ccc|}
\hline \multirow{2}{*}{ Kecamatan } & \multicolumn{3}{|c|}{ Laki-laki } & \multicolumn{3}{c|}{ Perempuan } \\
& $\mathbf{2 0 1 8}$ & $\mathbf{2 0 1 9}$ & $\mathbf{2 0 2 0}$ & $\mathbf{2 0 1 8}$ & $\mathbf{2 0 1 9}$ & $\mathbf{2 0 2 0}$ \\
\hline Ampenan & $46.662,00$ & $47.890,00$ & $48.275,00$ & $46.052,0$ & $46.874,00$ & $47.666,00$ \\
\hline Mataram & $43.852,00$ & $45.820,00$ & $44.851,00$ & $45.670,00$ & $46.717,00$ & $47.742,00$ \\
\hline Cakranegara & $33.611,00$ & $33.774,00$ & $33.898,00$ & $34.508,00$ & $34.681,00$ & $34.821,00$ \\
\hline Sandubaya & $39.464,00$ & $40.650,00$ & $41.824,00$ & $39.716,00$ & $40.916,00$ & $42.112,00$ \\
\hline
\end{tabular}




\begin{tabular}{|c|c|c|c|c|c|c|}
\hline \multirow{2}{*}{ Kecamatan } & \multicolumn{3}{|c|}{ Laki-laki } & \multicolumn{3}{|c|}{ Perempuan } \\
\hline & 201 & 2019 & 2020 & 2018 & 2019 & 2020 \\
\hline Sekarbela & $35.825,00$ & $37.147,00$ & $38.473,00$ & $36.746,00$ & $38.107,00$ & $39.481,00$ \\
\hline Selaparang & $36.812,00$ & $36.878,00$ & $36.900,00$ & $38.558,00$ & $38.631,00$ & $38.669,00$ \\
\hline Kota Mataram & $236.226,00$ & $240.789,00$ & $0245.190,00$ & $241.250,00$ & $245.926,00$ & $0250.491,00$ \\
\hline
\end{tabular}

\section{Sumber: BPS Kota Mataram}

Perkembangan penduduk di Kota Mataram cukup pesat dari data 2018 jumlah penduduk secara keseluruhan 236.226 jiwa penduduk laki-laki dan sebesar 241.250 jiwa penduduk wanita, total pendduduk tahun 2018 sebesar 477.467 jiwa. Pada tahun 2019 penduduk laki-laki mencapai 240.789 jiwa dan penduduk wanita berjumlah 245.926 jiwa atau total penduduk 2019 sebesar 486.715 jiwa atau meningkat sebesar 1,93 \%. Selanjutnya penduduk tahun 2020 merupakan angka prediksi yang digambarkan oleh kantor dukcapil kota Mataram dimana tahun 2020 penduduk laki-laki berjumlah 245.190 jiwa dan penduduk wanita sebesar 250.491 jiwa atau jumlah keseluruhan penduduk tahun 2020 sebesar 495.681 jiwa atau mengalami peningkatan dari tahun sebelumnya sebesar $1,84 \%$. Pertambahan jumlah penduduk yang cukup besar harus diimbangi dengan berbagai kebutuhan pokok makan, sandang maupun papan yang permintaannya cukup banyak, terutama permintaan akan produk-produk olahan baik sebagai bahan mentah maupun produk olahan industry kecil yang sudah jadi.

Karakteristik Pekerja Informal Dan Formal Gambaran mengenai karakteristik pekerja sektor informal danpekerja formal di Kota Mataram meliputi pekerja yang bekerja di sector informal dan pekerja di sector for yang secara fisual menunjukkan variabelvariabel yang diteliti. Deskripsi akan mencoba menggambarkan karakteristik responden berdasarkan gender, usia, pendidikan terakhir, tanggungan, jenis usaha, jam operasional usaha, lama usaha, modal usaha, dan pendapatan yang diperoleh. Adapun deskripsi dari beberapa karakteristik pekerja sektor informal tersebut adalah sebagai berikut:

\section{Karakteristik Pekerja Sektor Informal Dan Formal di Kota Mataram}

Berdasarkan hasil sampel responden dalam penelitian ini, didapatkan data mengenai persentase pada perkerja sektor informal maupun pekerja sector formal di wilayah kota Mataram yang menjadi responden dalam penelitian ini adalah sebesar 54 orang pekerja sector informal atau mencapai $60 \%$ dan 36 orang pekerja formal atau mencapai sebesar $40 \%$. Perbedaan persentase pekerja sektor informal tidak terlalu besar, dengan persentase pekerja sector formal dan lebih dominan dibandingkan persentase pekerja formal. Hal tersebut terjadi karena salah satunya dikarenakan ada kecenderungan penduduk lebih banyak yang menjadi pencari nafkah utama guna memenuhi kebutuhan rumah tangga dalam keluarga lebih memilih pekerjaan di sector informal dibanding formal yang lebih mengutamakan persyaratan pendidikan dan keahlian. Sedangkan pekerja di sector informal masuk tanpa membutuhkan keahlian dan persyaratan pendidikan untuk menekuni suatu bidang pekerjan atau usaha.

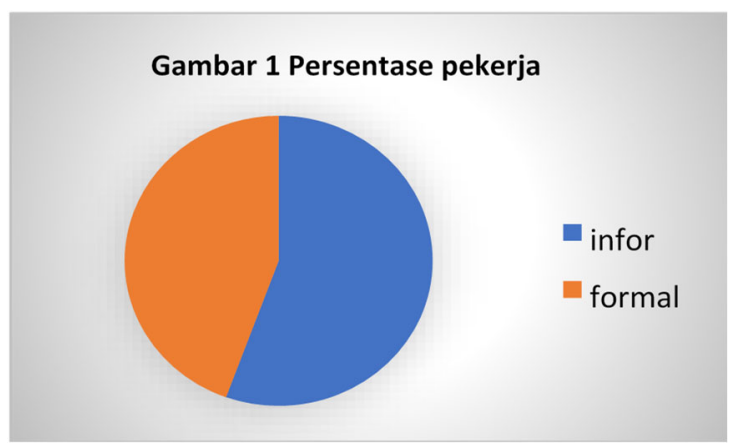

Sumber: data primer diolah (2020) 


\section{Karakteristik Pekerja Informal dan Formal Berdasarkan Usia}

Penyebaran penduduk dikota Mataram dapat dilihat dari jumlah penduduk menurut kelompok umur baik dari usia anak-anak sampai usia produktif dapat digambarkan berikut:

Jumlah pekerja sektor informal dan formal dengan usia produktif di wilayah penelitian menjadi mayoritas yaitu kisaran usia 21 tahun sampai dengan usia 56 tahun. Hal ini dapat dilihat dari besarnya persentase pekerja dengan usia antara 24 sampai dengan 35 tahun mencapai 30 responden atau $33.3 \%$. Sementara itu pekerja dengan umur > 35 sampai dengan 56 tahun sebanyak 54 orang atau $60 \%$ daripopulasi. Sedangkan sisanya merupakan pekerja dengan usia dibawah 24 tahun sebanyak 6 orang atau mencapai 6,7 \%. Dari gambaran usia kerja disektor informal maupun formal merupakan pekerja produktif yang sebagian besar berusia 35 tahun ke atas dan yang kedua usia kerja pada kisaran 24 - 35 tahun dan yang ketiga pekerja dengan usian dibawah umur 24 tahun. Umur seseorang dapat sangat menentukan keberhasilan suatu usaha karena pada usia antara 25 tahun keatas mereka sangat semangat dan membutuhkan penghasilan untuk membiaya hidup keluargausia dibawah 24 tahun masih merupakan usia baru untuk terjun memulai usaha sendiri maupun sebagai pekerja atau membantu pekerjaan sesorang sebgai tenaga kerjadan ini ditunjukkan dari tingkat produktivitas dalam menjalankan aktivitas usaha di sector informal maupun formal, hal ini berkaitan dengan kemampuan daya tahan fisik untuk menyelesaikan suatu pekerjaan dan kondisi seseorang secara fisik sangat berpengaruh terhadap setiap aktivitas pekerjaan yang ditekuninya.

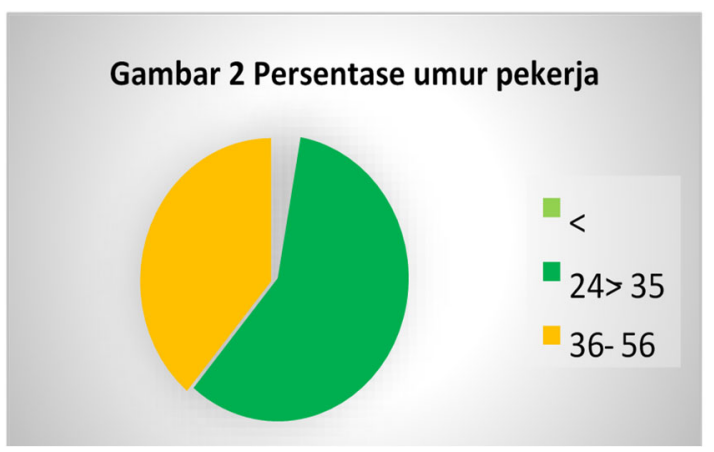

\section{Karakteristik Pendidikan Responden}

Pendidikan merupakan variable penting bagi seseorang dalam memasuki dunia kerja atau pasar kerja, karena dengan tingkat pendidikan yang dimilikinya maka seseorang akan dapat menentukan pilihannya untuk mengembil pekerjaan di sector mana karena disesuaikan dengan tingkat keahlian atau keterampilan yang dimilikinya. Dalam penelitian ini dari data sampel yang ada pendidikan responden dapat dikelompokkan menjadi ke dalam 4 kategori, yaitu tidak tamat SD, SD, SMP, dan SMA ke atas. Berdasarkan data lapangn Pekerja dengan tingkat pendidikan SMA ke atas menduduki posisi terbanyak di antara kategori yang lain dengan jumlah 34 responden diikuti dengan tingkat pendidikan SMP 22 responden, lalu Sarjana/Diploma 17 responden, pekerja dengan pendidikan tamat SD sebanya 13 responden dan kategori tidak tamat SD sebesar 4 responden. Artinya, walaupun pekerja di wilayah kota Mataram tersebut kebanyakan berasal dari masyarakat menengah kebawah, namun memiliki latar belakang pendidikan yang cukup tinggi yaitu SMA ke atas sebanyak 56,67 \% dari total responden dan selebihnya kategori pendidikan pekerja sebanyak 33,33 \% dengan pendidikan tamat SMP dan Sd dan $4,5 \%$ tidak tamat SD (4 orang resonden) pada pekerja informal. Sedangkan ratarata pekerja formal mememiliki pendidikan sarjana (S1) dan tamatan 
diploma (D III) yaitu sebanyak 17 orang responden atau $18,89 \%$.

Berdasarkan sebaran data didapati bahwa keberadaan pekerja informal maupun formal diihat dari tingkat pendidikan, dimana pekerja sektor informal didominasi oleh pekerja dengan pendidikan tamat SMA kebawah, sedangkan jenis usaha pekerja sektor informal maupun formal yang menamatkan sampai jenjang S1 memiliki usaha rumah makan, bingkil, Internet, potokopy, percetakan dan took. Berdasarkan gambar diagram 3, dapat dilihat bahwa pendidikan pekerja sektor infornal mayoritas pada jenjang pendidikan SMA ke bawah dengan persentase $81,0 \%$ atau sebanyak 73 orang responden. Hal ini dapat menunjukkan bahwa pekerja sektor informal yang kedudukannya sekunder dalam perekonomian kota Mataram namun tingkat kesadaran para pekerja sektor informal akan pentingnya pendidikan cukup tinggi. Walaupun, masih adanya responden yang tidak tamat sekolah dasar sebanyak $4,5 \%$ atau 4 orang responden.

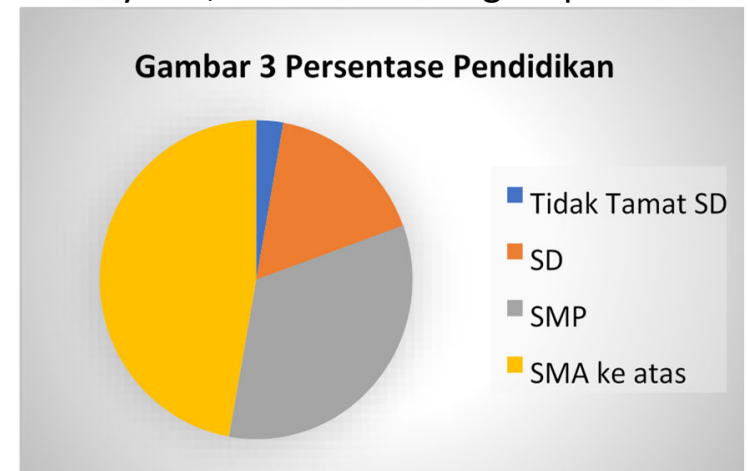

Sumber: data primer diolah (2020)

\section{Karakteristik Jumlah Tanggungan}

Pada gambar 4 dapat dilihat jumlah tanggungan pekerja sektor informal dan formal yang menjadi responden di wilayah kota Mataram sebarannya adalah sebagai berikut; pertama pekerja informal dan formal dengan jumlah tanggungan 2 orang sebanyak 35 orang responden atau sebesar 38,89\%, kedua terdapat pada tanggungan 3 orang sebanyak 28 responden atau sebesar 27,78 \%. Selebihnya responden dengan tanggungan
1 orang sebanya 10 orang responden atau sebesar $9 \%$, kemudian responden dengan tanggungan di atas 4 orang sebanya 14 responde atau sebesar 15,56 \% dan responden dengan tanggunga 0 orang artinya tidak memiliki beban tanggungan keluarga sebessar 3,33\% atau sebanya 3 orang responden. Kelompok responden ini didominasi oleh anak-anak muda yang statusnya belum menikah yang baru memulai bekerja di sector formal.

Beban tanggunga dalam keluarga pekerja informal maupun forma menjadi beban dalam pencapaian pendapatan pekerja yang menjadi ukuran apakah pendapatan yang diterima pekerja informal dan formal di wilayah kota Mataram sudah memenuhi standar Kebutuhan Hidup Layak (KHL) atau belum ini dapat diukur dengan membandingkan pendapatan yang diterima pekerja dengan standar KHL yang ada di Kota Mataram baik bagi pekerja lajang maupun pekerja status menikah.

Berikut sebaran jumlah tanggungan pekerja sector informal dan formal di wilayah Kota Mataram dapat ditampilkan dalam bentuk diagram yang menunjukkan persentase jumlah tanggunang dari tanggunga 0 kemudian 1, 2,3, dan di atas 4 orang.

Gambar 4 Persentase Tanggungan

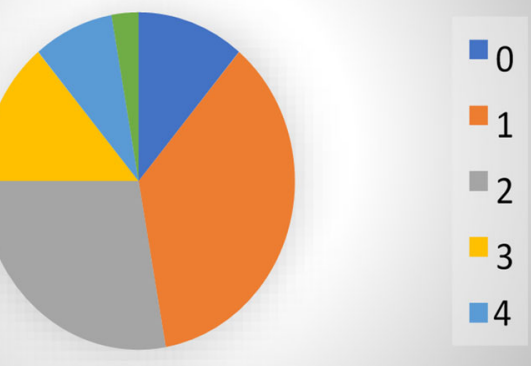

Sumber: data primer diolah (2020)

\section{Jenis Usaha Pekerja Informal dan Formal di Kota Mataram}

Jenis - jenis usaha yang dikelola oleh pekerja informa maupun formal diwilayah kota Mataram antara lain minuman/es juice, es the, es kelapa, kios/warung, rumah makan, laundry, jasa, rental, poto 
copy, percetakan, toko dan usaha lainnya. Sebaran data jenis usaha responden didominasi oleh usaha warung makan baik makanan matang maupun makanan mentah yaitu sebesar $41,11 \%$, kemudian diikuti jenis usaha minuman sebesar $10 \%$, toko sebesar $10 \%$ dan poto copy $7,8 \%$ Selanjutnya ada usaha laundry, tambal ban. Sol sepatu, gadai barang (jasa) sebesar 11,11 \%, usaha lainnya rental, internet dan bingkil kendaran dan konter HP total sebanyak 14 responden atau sebesar 15,56 \% (rental 3, internet 3, konter HP 3, bingkil 5).

Jenis usaha informal yang berada di wilayah kota Mataram terdiri dari kios/warung, minuman, makanan. ketiga wilayah ini Cakranegara, Mataram dan ampenanan merupakan daerah pemukian padat penduduk, disamping dekat dengan pusat-pusat pendidikan seperti kampus Universitas Mataram, Unizar, IAIN dan Universitas Muhamadiyah. Hal ini tidak terlepas secara tidak langsung menjadi peluang bisnis bagi masyarakat sekitarnya untuk mencari penghasilan dengan melakukan aktivitas usaha warung makan terbanyak, kios, jasa bingkil, jasa tambal ban, sol sepatu, photocopy, rental dan lainlain.

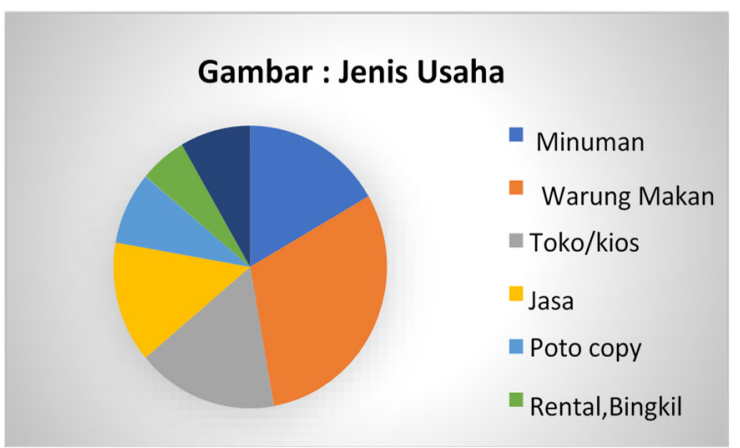

Sumber: data primer diolah (2020)

\section{Karakteristik Bedasarkan Waktu Bekerja}

Waktu kerja bagi pekerja informal dan formal dapat mempengaruhi pendapatan yang diterima pekerja informal maupun pekerja formal yang di mulai dari jam kerja awal sampai selesai bekerja. Kemampuan pekerja yang dicurahkan dalam waktu bekerja yang dapat diselesaikan dalam mencari nafkah dapat dilihat pada gambar 6. Berdasarkan reviu data penelitian dapat diketahui bahwa dari 90 responden waktu kerjanya dibagi menjadi 2 (dua) bagian yaitu bekerja $<10$ jam, bekerja diatas $>10$ jam, hal ini bila merujuk pada peraturan Menteri Tenaga Kerjaan Ketetapan Undang-Undang No. 13 Tahun 2003, tentang ketenagakerjaan adalah waktu bekerja selama 7 jam/hari untuk 6 hari kerja dalam seminggu (pasal 77 ayat 2 poin a), atau $8 \mathrm{jam} /$ hari untuk 5 hari kerja dalam seminggu (pasal 77 ayat 2 poin b). Kondisi ini menggambarkan sektor informal tidak terikat waktu dalam menjalankan usahanya. Pekerja sector informal maupun formal dari jam kerja yang diperoleh dalam penelitian sebagian besar jam kerjanya melampoi jam kerja normal yaitu 7 jam sehari. Dari data penelitian diketahui bahwa rata-rata yang bekerja < 10 jam sehari mencapai $40 \%$ atau 36 responden dan sisanya atau $60 \%$ atau 54 responden mereka bekerja melebihi 10 jam sehari.

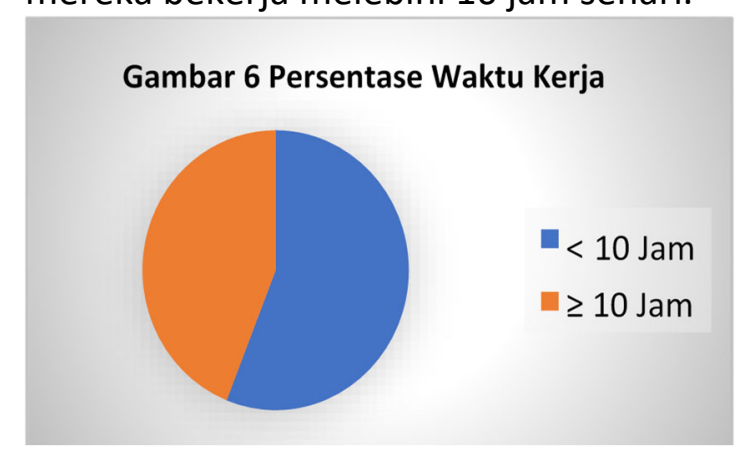

Sumber: data primer diolah (2020)

\section{Karakteristik Berdasarkan Lama Kerja}

Lamanya bekerja seseorang masuk dalam dunia kerja merupakan pengalaman pekerjaan yang ditekuninya dan ini akan memberi manfaat dari segi waktu dan kebiasaan mereka dalam melakukan aktivitas. Baik pekerja informal maupun formal sebagaian besar dari responden memiliki pengalaman bekerja dari sisi lama kerja diatas $>10$ tahun mencapai $65 \%$ atau sebanyak 61 rsponden dan dibawah 5 tahun sebanyak $10 \%$ atau sebanyak 9 
responden, sedangkan diatas 5 tahun sampai 10 tahun sebesar $25 \%$ atau sebanyak 20 orangBerdasarkan hasil data yang didapat dari lapangan, diketahui bahwa lamanya masa kerja yang dimiliki responden sedikit banyak akan mempengaruhi pendapatan yang diterima oleh pekerja informal maupun formal karena mereka sudah benar-benar memahami karakter bisnis dibidangnya.

Tabel 3. Lama Bekerja sector informal dan Formal

\begin{tabular}{|l|l|cc|cc|}
\hline & Lama Usaha & Informal (\%) & \multicolumn{2}{|c|}{ Formal (\%) } \\
\hline 1 & Dibawah 5 Tahun & 9 & $(10)$ & \multicolumn{2}{|c|}{} \\
\hline 2 & Diatas 5 s/d 10 tahun & 32 & $(36)$ & 15 & $(17)$ \\
\hline 3 & Diatas 10 tahun & 24 & $(26)$ & $10 \quad(11)$ \\
\hline
\end{tabular}

Sumber: data primerdiolah (2020)

Pada table 3. di atas dapat dilihat persentase perbandingan antara lama kerja dari pekerja sektor informa sebesar $72 \%$ atau sebaguian besar pekerja sector informal memiliki pengalaman berusaha diatas 5 mencapai 55 orang responden dan pekerja formal memiliki pengalaman usaha di atas 5 tahun sampaidengan 10 tahun sebanyak 25 rang responden. Dapat diketahui dari keseluruhan jumlah responden pekerja sektor informal sebagian besar memiliki pengalaman usahan diatas 5 tahun, dan begitu juga pada pekerja formal 5-10 tahun sebanya 15 orang responden dan diatas 10 tahun sebanya 10 orang responden. Sedangkan responden pekerja informal dengan lama usaha dibawah 5 tahun sebanyak 9 orang responden atau sebesar $10 \%$. Dapat disimpulkan bahwa disektor informal pengalaman bekerjanya pada usaha yang digelutinya a lebih mendominasi dibandingkan pekerja di sector formal di wilyah kota Mataram.

\section{Karakteristik Berdasarkan Modal}

Berdasarkan hasil penelitian di lapangan, diketahui frekuensi dan persentase modal pekerja informal. Terdapat 20 responden yang mengeluarkan modal dibawah $\mathrm{Rp}$ 4.000.000,- untuk usaha informalnya, dan diatas 5.000 .000 sampai dengan
10.000.000,- sebanyak 24 orang responden selebihnya dengan modal diatas $\mathrm{Rp}$ 10.000.000 - Rp 20.000.000 sebanyak 11 orang responden. Sealanjutnya pekerja disektor formal kepemilikan modal antaran Rp 5.000.000,sampai dengan Rp 10.000.000,-- sebanyak 5 orang responden dan dengan modal usaha di atas Rp 10.000.000,- - Rp 20.000.000 sebanyak 24 orang responden, dan usaha dengn modal di atas Rp 20.000.000,sebanyak 6 orang responden.

$\mathrm{Hal}$ ini mengindikasikan bahwa ukuran usaha atau pekerjaan disektor informal maupun formal diwilayah Kota Mataram klasifikasi modal yang dimiliki berbeda pekerja formal cendrung penggunaan modal usahanya lebih besar di banding pekerja informal. Perbedaan ini disebabkan karena membuka usaha formal memerlukan tempat dan biaya peralatan yang cukup tinggi yaitu mencapai puluhan juta. Adapun sebaran modal pekerja sektor informal dan formal diwilayah kota Mataram yang terbanyak adalah $\mathrm{Rp}$ 50.000.000 dengan jenis usaha ercetakan dan poto copy, internet mencapai $\mathrm{Rp}$ 40.000.000. Berikut sebaran modal usaha yang dimiliki pekerja sector informal dan formal diwilayah kota Mataram tahun 2020, sebagai berikut:

Tabel 4. Sebaran Modal Usaha Pekerja Informal Dan Formal

\begin{tabular}{|c|l|c|c|c|}
\hline No & \multicolumn{1}{|c|}{ Modal Usaha } & Informal & Formal & Keterangan( \%) \\
\hline 1 & Dibawah Rp 5.000.000 & 20 & - & Modal sendiri \\
\hline 2 & Rp 5.000.000-Rp 10.000.000 & 24 & 5 & Modal sendiri \\
\hline 3 & $>10.000 .000-20.000 .000$ & 11 & 24 & Pinjaman \\
\hline 4 & $>20.000 .000$ & - & 6 & Pinjaman \\
\hline
\end{tabular}


Sumber: Data primer diolah (2020)

Berdasarkan pada table 4 di atas, dapat dilihat persentase tingkatan modalyang dimiliki para pekerja sektor informal maupun formal. Selisih Persentase antara modal ratusan ribu dan modal jutaan tidak terlalu besar, hanya 2 \% yang artinya bahwa ukuran usaha atau pekerjaan di wilayah tersebut cukup besar untuk ekonomi kelas menengah mengingat jumlah modal yang dibutuhkan untuk membuat usaha atau pekerjaan tersebut cukup tinggi dan besar yaitu antara ratusan ribu hingga jutaan. Dapat dilihat juga Rp 2.154.167 ada $14 \%$ atau 5 orang responden pekerja sektor informal dengan tanpa modal, hal itu mungkin saja terjadi melihat pekerjaannya adalah seorang juru parkir.

\section{Analisis Pendapatan Pekerja Informal dan} Formal

Tabel 5. Sebaran Pendapatan Sebulan Pekerja Informal dan Formal Di Kota Mataram

\begin{tabular}{|l|l|l|l|l|l|}
\hline No & Pendapatan (Rp) & \multicolumn{2}{|l|}{ Informal (\%) } & Formal (\%) & Keterangan \\
\hline 1 & $\leq 3.000 .000$ & $15 \quad 16,67$ & - & $\begin{array}{l}\text { Rokok dan minuman, } \\
\text { jasa }\end{array}$ \\
\hline 2 & $>3.000 .000-5.000 .000$ & $25 \quad 27,78$ & $8 \quad 8,89$ & $\begin{array}{l}\text { Makanan, konter hp, } \\
\text { parfum }\end{array}$ \\
\hline 3 & $>5.000 .000-7.000 .000$ & 11 & 12,21 & $12 \quad 13,33$ & Warung, internet, bingkil \\
\hline 4 & $>7.000 .000$ & $4 \quad 4,45$ & $15 \quad 16,67$ & $\begin{array}{l}\text { Photocopy, cetakan, RM } \\
\text { Makan, Toko }\end{array}$ \\
\hline
\end{tabular}

Sumber: Data primer diolah (2020)

Mengacu pada ringkasan data pada tabel 5 di atas, dimana pendapatan pekerja informal sebahagian besar berpendapatan dibaah Rp 5.000.000,- atau sebanyak 40 orang responden atau 44,46\% dengan 15 $\%$ responden berada pada tingkat pendapatan dibauah $\mathrm{Rp} 3.000 .000,-$ dan 8 orang responden pekerja formal atau 8,89 $\%$ memperoleh pendapatan dibaah $\mathrm{Rp}$ 5.000.000,- Pekerja informal yang memperoleh pendapatan di atas $\mathrm{Rp}$ 5.000.000 keatas sebanyak 11 orang responden atau sebesar 12,21 \% dan pekerja formal yang memperoleh pendapatan di atas Rp 5.000.000 - Rp 7.000.000,- sebanyak 12 orang responden atau sebesar $13,33 \%$ (internet, bingkil,
Pendapatan merupakan penghasilan dari usaha berupa uang yang didapatkan oleh pedagang dalam satu hari kerja, yang dinyatakan dalam satuan rupiah dengan akumulasi selama satu bulan. Berdasarkan gambar 9 di bawah dapat dilihat dari segi pendapatan, mayoritas pekerja sektor informal di wilayah tersebut memiliki pendapatan di bawah $\mathrm{Rp} 1.500 .000$ yaitu sebanyak $72,2 \%$ atau 26 responden dari total jumlah responden. Artinya jika dilihat dari sisi ekonomi, menjadi pekerja sektor informal di wilayah tersebut adalah kurang menjanjikan dari segi ekonomi, namun mungkin akibat dari tuntutan hidup sehingga banyak masyarakat yang memilih mengais rezeki di sektor informal wilayah tersebur walaupun dengan pendapatan ala kadarnya. rental), dan perolehan pendapatan di atas Rp 7.000.000 sebanyak 4 orang responden pekerja informal atau 4,45 \% (rumah makan) dan perolehan pendapatan pekerja formal di atas $\mathrm{Rp} 7.000 .000$,sebanyak 15 orang responden atau 16,67 $\%$ berupa potho copy, cetakan, dan toko).

\section{Analisis Tingkat Pendapatan Dan Kesejahteraan Pekerja Informal dan Formal Di Kota Mataram}

Berdasarkan kriteria Sajogyo (1997), tingkat kesejahteraan rumah tangga dapat dilihat dari pengeluaran rumah tangga per kapita per tahun, yaitu total pengeluaran rumah tangga yang terdiri dari pengeluaran pangan dan non pangan dalam setahun dibagi dengan jumlah 
tanggungan rumah tangga. Guna mengukur tingkat kesejahteraan rumah tangga, pengeluaran rumah tangga per kapita per tahun kemudian dibagi dengan harga beras per kilogram, Besarnya pengeluaran per kapita per tahun yang diukur dengan harga atau nilai beras setempat untuk daerah perdesaaan adalah 1) Paling miskin, apabila pengeluaran/kapita/tahun lebih rendah dari $180 \mathrm{~kg}$ setara nilai beras/tahun. 2) Miskin sekali, apabila pengeluaran/kapita/tahun antara 181-240 kg setara nilai beras/tahun. 3) Miskin, apabila pengeluaran/kapita/tahun antara 241-320 kg setara nilai beras/tahun. 4) Nyaris miskin, apabila pengeluaran/ kapita/tahun antara 321-480 kg setara nilai beras/tahun. 5) Cukup, apabila pengeluaran/kapita/tahun antara 481-960 kg setara nilai beras/tahun. 6) Hidup layak, apabila pengeluaran/kapita/tahun lebih tinggi dari $960 \mathrm{~kg}$ setara nilai beras/tahun.

Tabel 6. Kebutuhan Hidup Layak Pekerja Informal dan Formal di Kota Mataram

\begin{tabular}{|c|c|c|c|c|c|}
\hline No & Uraian & $\begin{array}{l}\text { Pendapatan } \\
\text { (Rp)/bulan }\end{array}$ & $\begin{array}{l}\text { Kriteria } \\
\text { Sajogyo }\end{array}$ & $\begin{array}{l}\text { Jumlah } \\
\text { Pekerja }\end{array}$ & Keterangan \\
\hline \multirow[t]{10}{*}{1} & Pekerja Informal & & & & \\
\hline & $\begin{array}{l}\text { 1. Pedag Minuman } \\
\text { dan Rokok/K3 }\end{array}$ & 1.500 .000 & $450 \mathrm{~kg}$ & 5 & RT Nyaris Miskin \\
\hline & 2. Uarung Makan /K4 & 2.500 .000 & $750 \mathrm{~kg}$ & 15 & RT Hidup Cukup \\
\hline & $\begin{array}{l}\text { 3.Pedagang Lalapan } \\
\text { /K4 }\end{array}$ & 4.500 .000 & $1.800 \mathrm{~kg}$ & 5 & RT Hidup Layak \\
\hline & $\begin{array}{l}\text { 4.Pedagang } \\
\text { Gorengan /K4 }\end{array}$ & 2.500 .000 & $750 \mathrm{~kg}$ & 4 & RT Hidup Cukup \\
\hline & $\begin{array}{l}\text { 5. Pelayanan Jasa } \\
\text { (tukang jam, sul } \\
\text { sepatu /K4 }\end{array}$ & 1.500 .000 & $450 \mathrm{~kg}$ & 6 & RT Nyaris Miskin \\
\hline & $\begin{array}{l}\text { 6. Pedagang Sayuran } \\
\text { / K4 }\end{array}$ & 1.500 .000 & $450 \mathrm{~kg}$ & 4 & RT Nyaris Miskin \\
\hline & $\begin{array}{l}\text { 7.Pedagang } \\
\text { Martabak/K4 }\end{array}$ & 3.500 .000 & $1050 \mathrm{~kg}$ & 5 & RT Hidup Layak \\
\hline & $\begin{array}{l}\text { 8. Pedagang kaset, } \\
\text { topi /K4 }\end{array}$ & 3.000 .000 & $900 \mathrm{~kg}$ & 6 & RT Hidup Cukup \\
\hline & $\begin{array}{l}\text { 9. Pedagang Sate } \\
\text { ayam/K4 }\end{array}$ & 3.750 .000 & $1.125 \mathrm{~kg}$ & 5 & RT Hidup Layak \\
\hline \multirow[t]{8}{*}{2} & Pekerja Formal & & & & \\
\hline & $\begin{array}{l}\text { 1. Poto Copy dan Jilid } \\
\text { /K5 }\end{array}$ & 6.000 .000 & $1.144 \mathrm{~kg}$ & 8 & RT Hidup Layak \\
\hline & $\begin{array}{l}2 . \quad \text { Pedagang } \\
\text { Parfum/K4 }\end{array}$ & $4,000,000$ & $1.200 \mathrm{~kg}$ & 3 & RT Hidup Layak \\
\hline & 3. Internet/K3 & 4.500 .000 & $1.350 \mathrm{~kg}$ & 6 & RT Hidup Layak \\
\hline & 4. Kounter HP /K4 & 4.500 .000 & $1.350 \mathrm{~kg}$ & 6 & RT Hidup Layak \\
\hline & 5. Bingkil Motor/K5 & 4.500 .000 & $1.080 \mathrm{~kg}$ & 3 & RT Hidup Layak \\
\hline & 6. Loundry/K4 & 5.000 .000 & $1.500 \mathrm{~kg}$ & 3 & RT Hidup Layak \\
\hline & 7. Toko /K5 & 7.500 .000 & $1.800 \mathrm{~kg}$ & 6 & RT Hidup Layak \\
\hline
\end{tabular}

Sumber: Data Penelitian (2020)

Pendapatan pedagang rokok dan minuman rata-rata sebulan $\mathrm{Rp} 1.500 .000$,- dengan pendapatan sebesar itu setahun $\mathrm{Rp}$
18.000.000,- diasumsikan baha pendapatan habis untuk pengeluaran konsumsi dengan rata-rata 3 tanggungan 
keluarga, sehingga pendapatan perkapita setahun pedagang rokok dan minuman sebesar Rp 18.000.000: $3=$ Rp 6.000.000,Mengacu pada kritera yang dikemukakan Sayogyo bahua jika diukur dengan setara beras maka pendapatan pedagang rokok dan minuman setara dengan $600 \mathrm{Kg}$ beras yaitu diperoleh dari pendapatan perkapita dibagi dengan harga beras pada saat penelitian (Rp 10.000/kg) jadi $\mathrm{Rp}$ $6.000 .000,-: 10.000 .000=600 \mathrm{~kg}$ setara beras (hidup cukup).

Selanjutnya pedagang makanan (arung makan) dengan rata-rata pendapatan sebulan $\mathrm{Rp} \quad 2.500 .000$ sehingga pendapatan setahun $\mathrm{Rp}$ 30.000.000,dengan rata-rata tanggungan 4 orang, sehingga pendapatan perkapita setahun sebesar Rp 7.500.000,- jika diukur dengan kriteria Sayogyo dengan ukuran setara beras, maka Rp 7,500.000: 10.000 (harga beras $/ \mathrm{kg}$ ) $=750 \mathrm{~kg}$. apabila pengeluaran/kapita/tahun antara 481-960 kg setara nilai beras/tahun maka dikategorikan cukup.

Pendapatan pedagang lalapan ayam ratarata sebulan $\mathrm{Rp}$ 4.500.000,- dengan pendapatan sebesar itu setahun $\mathrm{Rp}$ 54.000.000,- diasumsikan bahua pendapatan habis untuk pengeluaran konsumsi dengan rata-rata 3 tanggungan keluarga, sehingga pendapatan perkapita setahun pedagang rokok dan minuman sebesar Rp 54.000.000: 3 = Rp 18.000.000,Mengacu pada kritera yang dikemukakan Sayogyo bahua jika diukur dengan setara beras maka pendapatan pedagang lalapan ayam setara dengan $1.800 \mathrm{Kg}$ beras yaitu diperoleh dari pendapatan perkapita dibagi dengan harga beras pada saat penelitian (Rp 10.000/kg) jadi Rp 18.000.000,-: $10.000 .000=1.800 \mathrm{~kg}$. Kriteria Sayogyo dikatakan hidup layak, apabila pengeluaran/kapita/tahun lebih tinggi dari $960 \mathrm{~kg}$ setara nilai beras/tahun. Selanjutnya pendapatan pedagang gorengan yang rata-rata pendapatan perbulannya Rp 2.500.000,- dengan rata- rata 3 tanggungan maka pendapatan perkapita setahunnya adalah Rp 2.500.000 $x 12 / 3=\operatorname{Rp} 6.000 .000,-$ Jika di ukur dengan setara beras maka dapat diperoleh $600 \mathrm{~kg}$ beras(Rp 6.000.000: 10.000) dan masuk kategori cukup.

Pekerja jasa (tukang jam, sul sepatu) memperoleh pendapatan sebulan sebesar $\mathrm{Rp}$ 1,500.000, pendapatan setahun sebesar Rp 18.000.000,- dengan jumlah tanggungan rata-rata 4 orang, sehingga pendapatan perkapita setahun sebesar Rp 18.000.000; $4=$ Rp 4.500.000,- atau dengan setara beras sebanyak $\mathrm{Rp}$ 4.500.000: $10.000=450 \mathrm{~kg}$. Jadi mengacu pada standar kriteria Sajogyo maka pendapatan yang diterima pekerja jasa ini masih dalam kategori nyaris miskin yaitu antara $321-480 \mathrm{~kg}$. Selanjutnya pedagang sayuran dengan rata-rata pendapatan sebulan Rp 1.500 .000 sehingga pendapatan setahun $\mathrm{Rp}$ 18.000.000,dengan rata-rata tanggungan 4 orang, sehingga pendapatan perkapita setahun sebesar Rp 4.500.000,- jika diukur dengan kriteria Sajogyo dengan ukuran setara beras, maka Rp 4.500.000: 10.000 (harga beras $/ \mathrm{kg}$ ) $=450 \mathrm{~kg}$. apabila dibandingkan dengan pengeluaran/kapita/tahun kriteria Sayogyo maka pendapatan pekerja pedagang sayuran ini di kategorikan nyaris miskin.. Nyaris miskin, apabila pengeluaran/ kapita/tahun antara 321$480 \mathrm{~kg}$ setara nilai beras/tahun.

Pendapatan pedagang martabak telur dan terangbulan sebulan Rp 4.500.000,sehingga pendapatan setahunnya sebesar Rp 54.000.000,- dengan tanggungan ratarata sebanyak 4 orang, maka pendapatan perkapita nya sebesar Rp 4.500.000 x 12 /4 $=\mathrm{Rp}$ 13.500.000,- atau setara dengan nilai beras sebanyak $\operatorname{Rp} 13.500 .000: 10.000=$ $1.350 \mathrm{~kg}$. Hal ini bila dibandingkan dengan kriteria Sayogyo, maka pendapatan dari pekerja pedagang martabak dan terang bulan ini dikatakan hidup layak karena pendapatan perkita dengan setara beras berada di atas $960 \mathrm{~kg}$ beras. Pekerja 
pedagang kaset, topi memperoleh pendapatan rata-rata sebulan sebesar $\mathrm{Rp}$ 3.000.000, pendapatan setahun sebesar Rp 36.000.000,- dengan jumlah tanggungan rata-rata 4 orang, sehingga pendapatan perkapita setahun sebesar Rp $36.000 .000 ; 4=\operatorname{Rp~9.000.000,-~atau~}$ dengan setara beras sebanyak $\mathrm{Rp}$ 9.000.000: $10.000=900 \mathrm{~kg}$. Jadi mengacu pada standar kriteria Sayogyo maka pendapatan yang diterima pekerja pedagang kaset dan topi ini masih dalam kategori cukup yaitu antara $480-960 \mathrm{~kg}$. Pendapatan pedagang sate ayam yaitu rata-rata sebulan sebesar $\mathrm{Rp} 3.750 .000$,pendapatan setahunnya sebesar $\mathrm{Rp}$ 45.000.000,- dengan rata-rata tanggungan sebanya 4 orang, sehingga pendapatan perkapita setahun sebesar $\operatorname{Rp~45,000.000,-~}$ : $4=\operatorname{Rp~11,250.000,-~atau~jika~di~}$ konversikan dengan setara beras sebesara Rp 11.250.000: $10.000=1.125$ kgberas. Jadi kesimpulannya pendapatan pekerja pedagang sate berada dalam kehidupan yang layak karena berada diatas $960 \mathrm{~kg}$.

Pendapatan pekerja formal yang bergerak dibidang poto copy dan cetak jilid dalam sebulan rata-rata pendapatannya $\mathrm{Rp}$ 6.000.000,- jadi pendapatan setahunnya Rp 72.000.000,-dengan rata-rata beban tanggungan keluarga sebanyak 5 orang, maka pendapatan perkapitanya adalah sebesar = Rp 72.000.000; $5=\mathrm{Rp}$ 14.400.000,- atau jika disetarakan dengan ukuran beras yaitu sebanyak $1.440 \mathrm{~kg}$, jadi pendapatan pekerja formal masuk kategori dalam kehidupan layak. Selanjutnya pendapatan pekerja formal dengan usaha pedagang parfum, pendapatan rata-rata sebulan $\mathrm{Rp}$ 4.000.000,- sehingga pendapatan pertahunnya sebesar $\mathrm{Rp}$ 48.000.000,- dengan rata-rata tanggungan sebanyak $4 \mathrm{~b}$ orang. Jadi pendapatan perkapitanya sebesar $\mathrm{Rp}$ 48.000.000: $4=$ 12.000.000,- atau dengan ukuran setara beras sebanyak $1200 \mathrm{~kg}$ beras.

Analisis Tingkat Kesejahteraan Pekerja Informal dan Formal
Berdasarkan kriteria Sajogyo (1997), tingkat kesejahteraan rumah tangga dapat dilihat dari pengeluaran rumah tangga per kapita per tahun, yaitu total pengeluaran rumah tangga yang terdiri dari pengeluaran pangan dan non pangan dalam setahun dibagi dengan jumlah tanggungan rumah tangga. Guna mengukur tingkat kesejahteraan rumah tangga, pengeluaran rumah tangga per kapita per tahun kemudian dibagi dengan harga beras per kilogram, Besarnya pengeluaran per kapita per tahun yang diukur dengan harga atau nilai beras setempat untuk daerah perdesaaan adalah 1) Paling miskin, apabila pengeluaran/kapita/tahun lebih rendah dari $180 \mathrm{~kg}$ setara nilai beras/tahun. 2) Miskin sekali, apabila pengeluaran/kapita/tahun antara 181-240 kg setara nilai beras/tahun. 3) Miskin, apabila pengeluaran/kapita/tahun antara 241-320 kg setara nilai beras/tahun. 4) Nyaris miskin, apabila pengeluaran/ kapita/tahun antara 321-480 kg setara nilai beras/tahun. 5) Cukup, apabila pengeluaran/kapita/tahun antara 481-960 kg setara nilai beras/tahun. 6) Hidup layak, apabila pengeluaran/kapita/tahun lebih tinggi dari $960 \mathrm{~kg}$ setara nilai beras/tahun.

Hasil penelitian ini menunjukkan bahua dari 90 responden dimana 9 orang responden atau $10 \%$ pekerja informal pendapatan perkapitanya jika diukur dengan tingkat kesejahteraan kriteria Sajogyo berada pada rumah tangga nyaris miskin(antara $231 \mathrm{~kg}$ - $480 \mathrm{~kg}$ setara beras). Selanjutnya yang masuk kategori Rumah Tangga hidup berkecukupan sebanyak 30 orang atau $34 \%$ dengan ratarata pendapatan perkapita pertahun sebesar Rp 7.125.000,- atau jika disetarakan beras sebesar $713 \mathrm{~kg}$. Kriteria Sajogyo rumah tangga hidup cukup jika pendapatan perkapita/tahun mencapai antara 480 - $960 \mathrm{~kg}$ setara beras dan ini berada pada responden pekerja informal. Pekerja yang masuk kategori rumah tangga 
hidup layak dengan rata-rata pendapatan perkapita/tahun sebesar Rp 11.750.000,-atau jika dikonversikan dengan setara beras sebesar $1.175 \mathrm{~kg}$ per tahun, sebanyak 15 orang pekerja informal atau 17 \%. Sedangkan pekerja sektor formal rata-rata pendapatan perkapita/tahun sebesar Rp 15.428.571,43 atau jika dibagi dengan harga beras saat penelitian (tahun

\section{KESIMPULAN DAN SARAN Kesimpulan}

Berdasarkan hasil perhitungan analisis yang telah dilakukan maka didapatkan kesimpulan dari penelitian ini, ialah:

1. Karakteristik pekerja informal sebagian besar berjualan ditempat-tempat keramaian yang padat penduduk dan pengunjung di Kota Mataram dengan rata-rata lama aktu bekerja > 10 jam sehari begitu pula dengan pekerja sektor formal bekerja hingga lebih dari 10 jam perhari.

2. Pendapatan pekerja informal sebagian besar yaitu hampir $50 \%$ tingkat kesejahteraannya diambang cukup, dan $10 \%$ nayris miskin menurut kriteria
2020) Rp 10.000,- per kg, maka pendapatan perkapita/tahun diperoleh $1.543 \mathrm{~kg}$ beras. Artinya bahua rata-rata pendapatan perkapita/tahun pekerja formal telah berada pada tingkat rumah tangga berkehidupan layak(mencapai 39 \%) dari 35 jumlah responden pekerja formal.

Sayogyo yang diukur dengan setara beras.

3. Pendapatan pekerja formal rata-rata pendapatan yang diterima jika diukur dengan tingkat kesejahteraan Sayogyo berada pada tingkat sejahtera (40\%) dan $10 \%$ berada pada ambang batas cukup.

\section{Saran}

1. Pekerja informal hendaknya dapat menambah jam Uaktu kerja untuk dapat menambah pendapatannya.

2. Pekerja informal terutama pedagang makanan olahan untuk dapat menggunakan aplikasi media pemasaran menggunakan go food dan gojek.

\section{DAFTAR PUSTAKA}

2013. Dinas Tenaga kerja Kota Mataram Badan Pusat Statistik Nusa Tenggara Barat. Februari 2019 Badan Pusat Statistik (BPS) Kota Mataram. Februari 2019 Hasil kajian Badan Pusat Statistik (BPS) Nasional (Februari,2019) Studi Profil Pekerja di Sektor Informal dan Arah Kebijakan. Direktorat

Ketenagakerjaan dan Analisis Ekonomi. (http://.bappenas.go.id)2014

Arikunto, Suharsini.2006. Prosedur Penelitian. Suatu pendekatan Praktik. PT. Reneka Cipta. Jakarta

Hasbul.2019. Tingkat Pengangguran NTB Masih Tinggi. Suara NTB, 27 Februari 2019

Aryo Demarto, dkk. 2003. Sektor informal alternatip kesempatan kerja Bagi Golongan

Berpendidikan Rendah. Makalah Diklat Universitas Sebelas Maret.

Kartasasmita M. 2011. Pengertian Agroindustri. Blokspot.com. 2011

Mubyarto.1998; Konsep Biaya Industri Kecil. Gramedia Jakart

Nasir, Mohammad; 1999. Metode Penelitian sosial. Graha Indonesia. Jakarta.

Sugiyono.2018. Metode Penelitian Kuantitatif Kualitatif dan R\&D. Bandung Alfabeta 
194 | Satarudin, Suprianto, Sujadi / Survey Pekerja Sekttor informal Dan.,.; Formal ...

Yupi Kurniauan,S dan Rr. Retno Arnanti(2014). Analisis Pengelolaa SumberdayaManusia Sektor Formal Dan Sektor Informal Di Jaua Timur.Jurnal AGORA Vol 2 No. 1

Yustina Chrismandani, dkk. 2014. Tenaga Kerja nSektor Formal dan Informal Di Kabupaten Bangkalan. Jurnal Media Trend. 2018. Universitas

Trunojoyo Madura.Yoeti, A. O. 1982. Pengantar Kepariwisataan, Sebuah Pengantar Perdana, Pradya Paramitha, Bandung. 